\title{
Estimation of rice vegetation coverage from DVI of Landsat 7 and 8 data
}

- Phan Thi Anh Thur

- Rikimaru Atsushi

- Kenta Sakata

- Kazuyoshi Takahashi

- Junki Abe

Nagaoka university of Technology, Japan

(Manuscript Received on June $28^{\text {th }}$, 2016, Manuscript Revised August 18 ${ }^{\text {rd }}$, 2016)

\begin{abstract}
Monitoring of rice growth is a requirement red and near-infrared bands of Landsat 7 and 8 were calculated from the field observation data. Satellite reflectance was also converted from pixel value of Landsat images. According to the data analysis, $V C$ rapidly increased in two fields and got saturation status (VC>90\%) at 65 days after transplanting (DAT) in the early July. DVI was approximately $25 \%$ when VC saturated. Additionally, DVI had strong correlation with $V C$ with high determination coefficient $\left(r^{2}=0.9\right)$ when VC was less than 90\%. Thus, VC were computed from DVI, calculated from reflectances of Landsat images, using a regression model of VC and DVI. From the result of comparison between the estimated and computed VC, the possibility of estimating VC from DVI calculated from Landsat reflectance is confirmed. The reflectances of paddy field corresponding to
\end{abstract}

Keywords: DVI, vegetation coverage, Landsat data, reflectance

\section{INTRODUCTION}

Rice is the main food of many countries, especially in Asian countries. Nowadays, customers demand affordable and safe rice with high quality of taste. To satisfy such requirements, many researches have been performed for improving the quality of rice. Therefore, the information of rice development stages in paddy field has been observed because

\section{Trang 138}


rice growth directly effects on rice quality. Physical parameters of rice (plant height, number of stem,...) change rapidly during rice growing season (Figure 1). They have been manual measured periodically to control the rice growth by deciding amount of adding fertilizer. Such directly measuring methods need a lot of time and working labor. Moreover, their accuracy depends on sample size and sampling position. Therefore, time- and labor-saving methods such as remote sensing techniques are considered a useful alternative and are widely utilized for monitoring rice crop [1].

Additionally physical parameters of rice plant, rice growth can be indicated from many parameters such as leaf color [2], leaf area index (LAI), leaf nitrogen content, fresh and dry weight,... In this study, vegetation coverage
(VC) showing the percent cover of rice plant was focused. VC has been validated as a good predictor variable for plant growth parameters such as leaf area index [3], above ground biomass and nitrogen content [4]. Moreover, VC affects on plant self-shading, neighbour-plant competition and amount of solar energy that rice plant could be received. Due to the expectation of obtaining VC in large area of paddy fields, remote sensing technique is suggested. The purpose of this study is to estimate rice vegetation coverage from difference vegetation index (DVI) computed from Landsat surface reflectance. DVI, mentioned here, is the difference reflectance of of near-infrared and red band. This index is strongly sensitive to green vegetation.

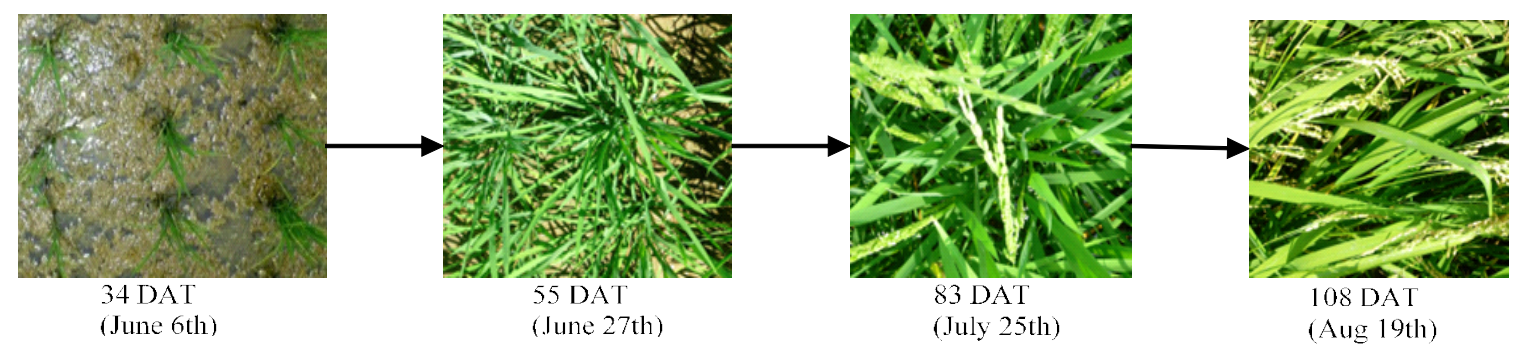

Figure 1. The change of rice canopy during rice development season

Table 1. Important date

\begin{tabular}{|c|c|c|c|c|}
\hline Field & Rice variety & Transplanting date & Heading date & Harvesting date \\
\hline A & Gohyakumangoku & May $03^{\text {rd }}, 2013$ & July $21^{\text {st }}, 2013$ & Aug $29^{\text {th }}, 2013$ \\
\hline B & Koshihikari & May $25^{\text {th }}, 2013$ & Aug $10^{\text {th }}, 2013$ & Sep $21^{\text {st }}, 2013$ \\
\hline \\
Ishikawa \\
Sanazawa
\end{tabular}

Figure 2. Study area 


\section{STUDY AREA}

The trial paddies are located in Niigata prefecture, known as rice capital of Japan. Because the weather is getting cool in Autum and snow appears during the winter, there is only one rice growing season from May to September. Paddy fields will be plowed in April, filled with water and prepared for planting. For this study, because of limited time and manpower, there was only two paddy rice varieties (Gohyakumankoku and Koshihikari) were chosen in Koshijinakazawa, Nagaoka City. In order to facilitate the equipment movement and data collection, two adjacent paddies were considered to select (Figure 2). Each paddy field had a standard width of 30 meters and 90 meters in length. They were planted with about 20 day old seedlings in May, 2013 (Table 1).

\section{RESEARCH DIRECTION}

The research direction is visually displayed in figure 3. To explain it in more details, the field observations were performed many times within study period by using spectrometer and digital camera. From spectral data the field reflectance was calculated. Then, the field reflectance corresponding to red and near infrared band (NIR) of Landsat 7 and 8 were computed. Field DVI was computed as the difference of NIR and red band. Additionally, right after satellite reflectance was converted from pixel value of Landsat images [5], satellite DVI was also computed. In next step, the relationship between field reflectance and satellite reflectance was investiagted. Moreover, VC was calculated from the photos of paddy fields. The relationship between VC and spectral reflectance was constructed by checking their changes in value over time. Finally, the posibility of estimating $\mathrm{VC}$ from satellite reflectance was investigated.

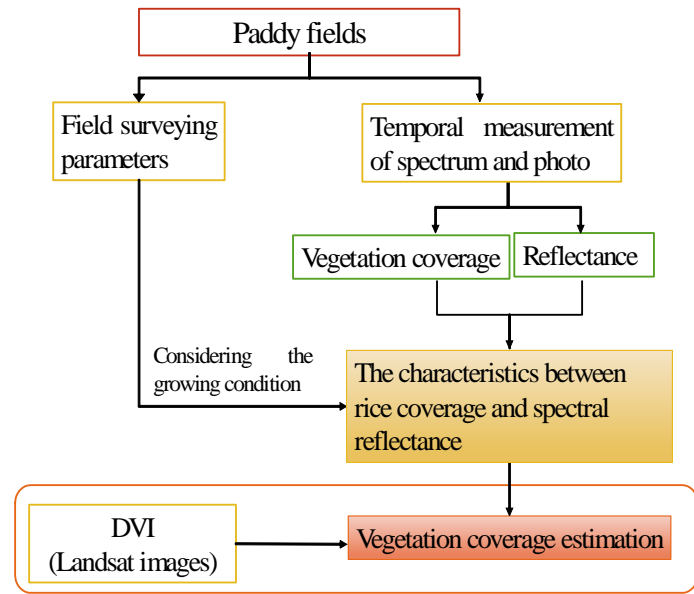

Figure 3. Research flow chart

\section{FIELD OBSERVATION}

For field observation, spectrometer Ocean Optics SD2000 in the range of visible light to infrared (340 nm $\sim 1025 \mathrm{~nm}$ ) was mounted on a steel bar placed on two tripods. The laptop in which the software was run to collect spectral data of paddy fields was connected to spectrometer using cable (Figure 4). All field observations were carried out in 2013. There were 12 observations for each paddy and 24 observations in total (Table 2). For each observation, there were two sizes of target area. Such target areas were observed for each trial field. The first one was wide area including rice plant and background (shadow, soil, water...) (Figure 4a). The second one was narrow area including rice plant only (Figure 4b). The radiation intensity of skylight and reflected radiation from the object surface were acquired at the same time by using two spectral cable assembling to two black tubes. For each target objects, these data were recorded 5 times. In case of wide target area, two tube receiving skylight and reflected light intensity were installed at the height of $1.25 \mathrm{~m}$ in field $\mathrm{A}$ and $1.34 \mathrm{~m}$ in field $\mathrm{B}$ with $46^{0}$ field of view. Moreover, photos of paddy fields were taken

\section{Trang 140}


every minute with spectral data by a digital camera in nadir direction. They were used to calculate rice coverage in paddy fields. Furthermore, there were five rice plants which were chosen to measure the physical parameters in each field. The average value calculated from that would be considered as representative value of whole paddy field.

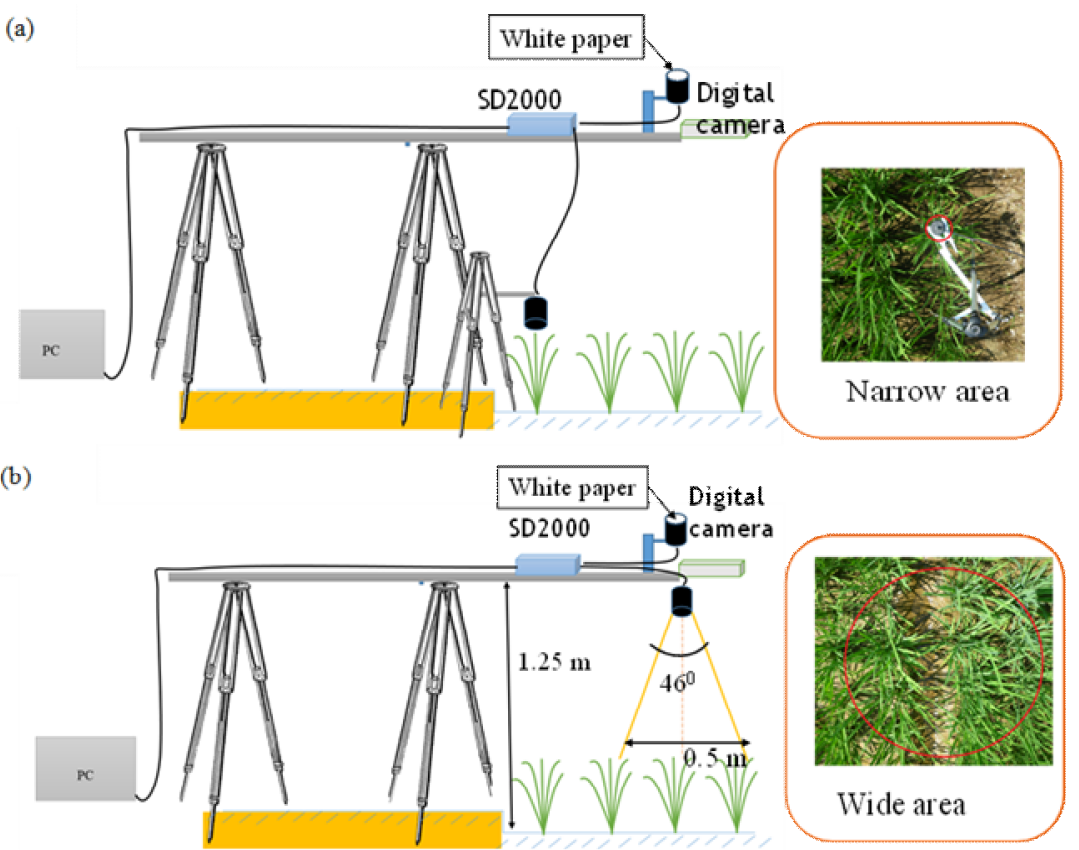

Figure 4. Field observations with (a) wide and (b) narrow area

Table 2. Field observation date

\begin{tabular}{|l|l|l|l|l|l|}
\hline Date & Observed field & Date & Observed field & Date & Observed field \\
\hline $06 / 06 / 2013$ & A & $16 / 07 / 2013$ & A and B & $22 / 8 / 2013$ & A and B \\
\hline $12 / 06 / 2013$ & A & $19 / 07 / 2013$ & A and B & $26 / 8 / 2013$ & A and B \\
\hline $13 / 06 / 2013$ & A & $22 / 07 / 2013$ & A and B & $29 / 8 / 2013$ & A and B \\
\hline $20 / 06 / 2013$ & A and B & $25 / 07 / 2013$ & A and B & $2 / 9 / 2013$ & A and B \\
\hline $24 / 06 / 2013$ & A and B & $30 / 07 / 2013$ & A and B & $4 / 9 / 2013$ & A and B \\
\hline $27 / 06 / 2013$ & A and B & $02 / 08 / 2013$ & A and B & $10 / 9 / 2013$ & B \\
\hline $01 / 07 / 2013$ & A and B & $06 / 08 / 2013$ & A and B & $17 / 9 / 2013$ & B \\
\hline $04 / 07 / 2013$ & A and B & $08 / 08 / 2013$ & A and B & $20 / 9 / 2013$ & B \\
\hline $08 / 07 / 2013$ & A and B & $15 / 08 / 2013$ & A and B & & \\
\hline $11 / 07 / 2013$ & A and B & $19 / 08 / 2013$ & A and B & & \\
\hline
\end{tabular}




\section{RESULTS}

\subsection{Rice coverage rate}

Vegetation coverage (VC) shows the percentage of area covered by rice plant per one-unit area of paddy field. VC changes easily and corresponds the change of rice canopy. Moreover, its value is affected by the physical parameters of rice and depends on the transplanting density. To calculate VC, greenness index was calculation to enhance plant pixels from 8-bit color red, green, blue images using equation 1 (Figure 5). The threshold value of plant pixels was identified due to the useful of pseudo-color image. VC was computed by taking the ratio of plant pixels to total pixels of digital camera image of rice field (eq. 2). As a result, VC almost linearly increases from early growing season in both fields. VC in field B increases sooner than field A. Different cultivar and transplanting date could be mentioned as an explanation. At 65 days after transplanting (DAT) VC is $90 \%$. The $90 \%$ of $\mathrm{VC}$ is assumed as the saturation of rice canopy. After 65 DAT, VC did not significantly change and it decreased before harvesting time (Figure 6).

$$
\begin{aligned}
& \text { Greenness }=100+\frac{2 \text { Green }-(\text { Blue }+ \text { Red })}{510} 100 \\
& V C(\%)=\frac{\text { The number of vegetation pixels }}{\text { Total pixel of the photo }} 100
\end{aligned}
$$

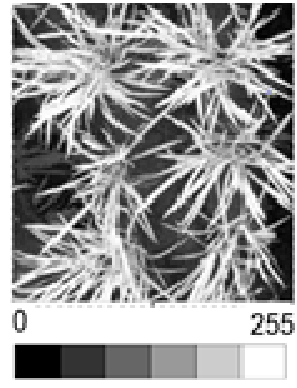

(a) Greenness image

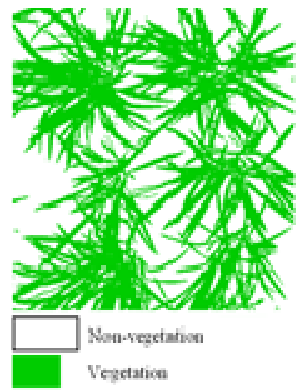

(b) Classified image
Figure 5. Plant pixels indentification

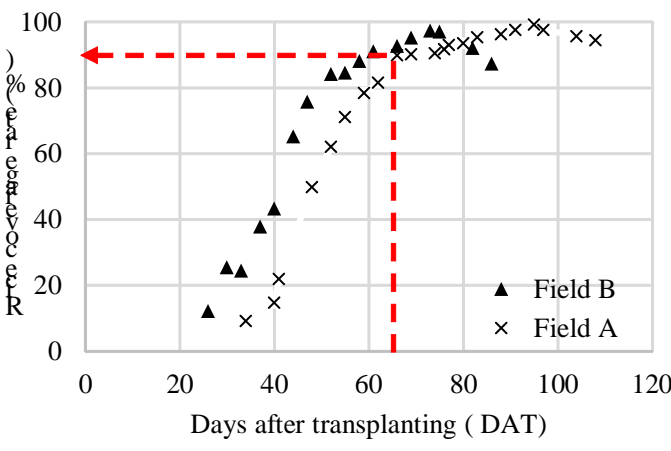

Figure 6. Rice coverage changes during development seasons

\subsection{Field reflectance calculation}

Regarding to the fundamentals, the reflectance has been calculated as the ratio between the intensity of light reflected from the object surface and the intensity of the incident light. However, in the process of data acquisition, there was a factor that affected data processing. To acquire the intensity of the skylight and reflected light from the object surface there were two spectral cables. One spectral cable end was attached to the spectrometer and another one was attached to a black hollow plastic tube with one end. Each tube was high $4.4 \mathrm{~cm}$ and its diameter was 3.8 $\mathrm{cm}$. Because the intensity of skylight was many times as much as the intensity of the light reflected from ground objects surface it was difficult to collect them at the same time. When the field observation was performed, in case of the cable receiving energy from sunlight, the tube was covered by a white paper on the top to reduce the intensity of the skylight (Figure 4). Therefore, intensity of the skylight had to be adjusted by the transmittance coefficient $\left(T_{\lambda}\right)$ of the white paper. Wavelength and intensity of experimental data were also calibrated [6] before calculating the reflectance (eq.3)

$$
R_{\lambda}=\frac{I_{1}}{I_{0}} T_{\lambda}
$$

\section{Where}

\section{Trang 142}




$$
\mathrm{R}_{\lambda} \text { : reflectance }
$$

$I_{1}$ Intensity of reflected light from target object

$$
I_{0} \text { : Intensity of skylight }
$$

$\mathrm{T}_{\lambda}$ : Transmittance coefficient

The characteristic of reflectance in visible and near- infrared region in which healthy green vegetation had a characteristic interaction with energy was special focused. The field reflectance corresponding to visible and nearinfrared bands of Landsat 7 and 8 were computed. As a result, the strongly development in vegetative phase leads to high reflection in near-infrared channel (NIR). The reflectance in NIR is many times as much as its value in visible band. To obtain rice growth, difference vegetation index (DVI) responding primarily to green vegetation was calculated as the difference reflectance of NIR and red band. Its value increased linearly prior to 65 DAT (Figure 7). This result confirmed the strong development of rice plant in vegetative phase with the rapid increase of rice foliage. Moreover, DVI was approximately equal $25 \%$ at 65 DAT. Before harvesting, green leaf area decrease and rice seed appearance caused reflectance non-increase in NIR band and reflectance advance in visible band. However, DVI did not have significant change because the reflectance in NIR band was many times as much as visible band.

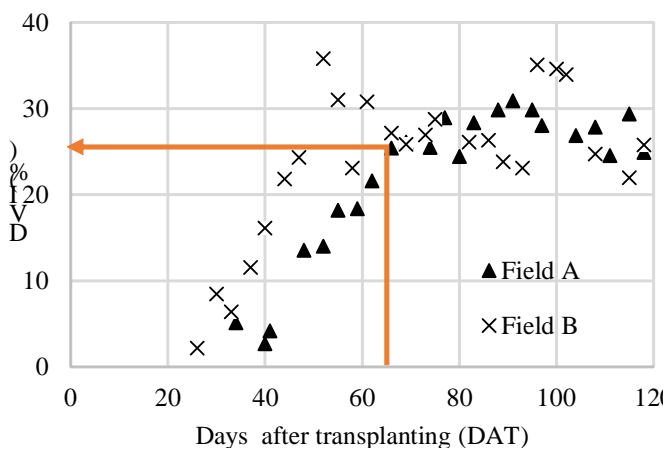

Figure 7. Change of field DVI

\subsection{Estimation of vegetation coverage from satellite DVI .}

There were 10 Landsat ETM+ and Landsat 8 images acquired from June to August of 2013. However, five of them had poor quality. The study area could not be observed from these images because of cloud cover. Finally, only 5 images collected on June 4, June 12, Jun 28, August 15 and August 31 were used in this study. Right after two pure pixels of paddy in which trial fields were located were extracted from satellite images, satellite DVI was calculated. The field DVI of such pixels was extended from field reflectance obtained in sample area without concerning extended errors. The field DVI corresponding to satellite observation date was estimated from field observation results. Satellite and field DVI were compared together. As a result, satellite DVI was almost smaller than field DVI. Linear regression attempts to model the relationship between satellite and field DVI was applied by fitting a linear equation to observed data. As a result, the high determination coefficient was determined $\left(r^{2}=0.9\right)$.

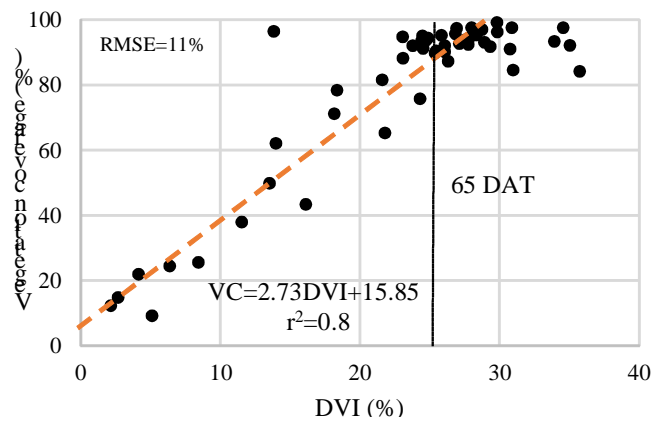

Figure 8. The relationship between DVI and vegetation coverage

Futhermore, the increase of field DVI corresponded to VC increase in the early period. With less than $90 \%$ of $\mathrm{VC}$, the linear correlation of DVI and VC was determined with high determinetion coefficient $\left(r^{2}=0.9\right)$. We expected that VC could be estimated from satellite DVI 
using empirical model (Figure 8). However, two rice varieties caused various respondent of spectral reflectance. After saturation of $\mathrm{VC}$, the increases of reflectance did not depend on VC. Additionally, the satellite and field DVI differed in their values. Therefore, some values of estimated VC were over valid value. Although estimated VC with RMSE of $15 \%$ did not as good as our expectation, the possibility of estimation of VC was considered.

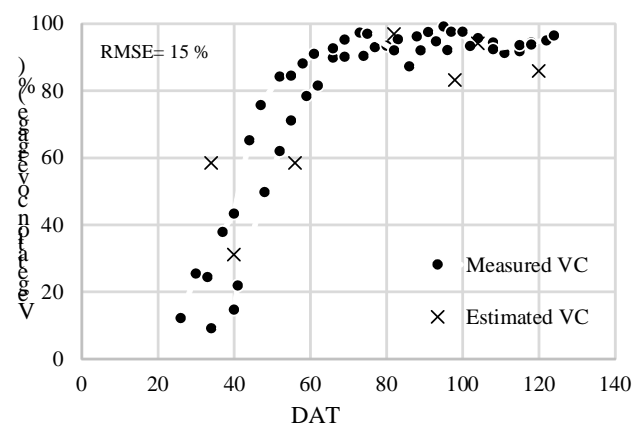

Figure 9. Estimated vegetation coverage

\section{CONCLUSION}

According to data analysis results, VC linearly increased in early period. It saturated (VC $\geq 90 \%$ ) in early July at 65 DAT. When VC saturated DVI was approximately $25 \%$. The $25 \%$ of DVI has been considered as the threshold value to identify the paddy field from satellite images. The reflectance indicated the rice growth prior to saturation of VC. Moreover, VC correlated to field DVI with high coefficient of determination $\left(r^{2}=0.9\right)$. With less than $90 \%$ of $\mathrm{VC}$, the regression model of VC was determined with $r^{2}=0.9$. Satellite DVI was applied to the model in order to estimate VC. That estimated VC matched on VC calculated from paddies photos confirmed the posibility of estimating VC from satellite DVI (Figure 9). Although the result was not as good as our expectation, the possibility of estimation of VC was confirmed. The model could be used to calculate the VC with satellite DVI. However, the model was possible only if vegetation coverage was less than $90 \%$. When VC saturated, some estimated VC was interpolated over valid value. At this time, instead of vegetation coverage as well as physical parameters, fertilizer and rice quantity contribute to the increase of field spectral reflectance.

\section{Ước tính độ phủ thực vật của lúa từ chỉ số DVI được tính từ ảnh Landsat 7 và 8}

- Phan Thị Anh Thư

- Rikimaru Atsushi

- Kenta Sakata

- Kazuyoshi Takahashi

- Junki Abe

Trường đại học Công nghệ Nagaoka, Nhật Bản 


\section{TÓM TẮT:}

Theo dõi sự phát triển của cây lúa là yêu cầu cần thiết, phuc vu cho công tác sản xuất lúa gạo chất luợng cao. Bên cạh chiều cao, số lương nhánh, màu sắc lá lúa, độ phủ thực vật hay tỷ lệ che phủ mặt đất của cây lúa cũng là một chỉ số được dùng trong việc đánh giá sư tăng trương của cây lúa. Trong nghiên cưu hiện tại, độ phủ thưc vật được uớc tính tù giá trị DVI (Difference Vegetation Index). DVI đườc sü dụng trong nghiên cúu này là giá trị sai biệt độ phản xa phổ của kênh gần hồng ngoại và kênh đỏ của các ảnh vệ tinh Landsat 7 và 8 . Thục nghiệm auợc tiến hành trên hai ruộng lúa với hai giống lúa riêng biệt vào năm 2013. Giá trị phổ của ruộng lúa được ghi nhận bởi thiết bị đo quang phổ Ocean Optics SD2000. Bề mặt của ruộng lúa được chụp bằng máy ảnh kỹ thuật số gắn kèm trên thiết bị đo ở độ cao 1 mét so vói mặt đất. Độ phủ thục vật thực tế của cây lúa đuợc tính trục tiếp tù các hình ảnh này. Giá trị phản xạ trên mặt đất được tính toán và chuyển đổi thành giá trị phản xa tuoong úng với kênh đỏ và kênh gần hồng ngoại của ảnh vệ tinh Landsat 7 và 8 trong khi giá trị phản xa của ảnh vệ tinh được chuyển đổi tù các giá trị pixel của ảnh. Theo kết quả phân tích số liệu, độ phủ của cây lúa gia tăng liên tục và đạt trạng thái bão hòa (độ phủ $\geq 90 \%$ ) ở đầu tháng 7 vào thời điểm 65 ngày sau khi cấy. Tại thời điểm bão hòa của độ phủ DVI xấp xỉ đạt $25 \%$. Bên cạh đó sụ tuoong quan mật thiết giũa độ phủ và giá trị DVI cũng được xác định với hệ số xác định cao $\left(r^{\wedge} 2=0.9\right)$ khi độ phủ chura đạt trạng thái bão hòa. Tù đó mô hình hồi quy được thành lập và sau đó giá trị DVI tính tù ảnh Landsat 7 và 8 dược áp dụng vào trong mô hình nhằm vớc tính giá trị độ phủ. Giá trị độ phủ uoóc tính phù hợp với giá trị độ phủ thực tế cho thấy khả năng sủ dụng độ sai biệt phản xa phổ của ảnh vệ tinh Landsat trong việc ước tính độ phủ thực vật của cây lúa.

Tù khóa: DVI, độ phủ thực vật, ảnh Landsat, độ phản xạ.

\section{REFERENCES}

[1]. Yoshirari Oguro, Monitoring of rice field by Landsat 7 ETM+ and Landsat 5 TM data, The 22nd Asian Conference on Remote sensing, 2001.

[2]. V. K. Choubey and Rani Choubey, Spectral Reflectance, Growth and Chlorophyll Relationships for Rice Crop in a Semi-Arid Region of India, Water Resources Management 13, pp 73-84, Kluwer Academic Publishers, 1999.

[3]. D. Nielsen, J.J.Miceli-Garcia, D.J.Lyon, Canopy cover and leaf area index relationships for wheat, tritical and corn, Agronomy Journal, Vol 104, Issue 6, 2012
[4]. S.Takemine, A. Rikimaru, K. Takahashi, Y. Higuchi, Basic study for estimation of nitrogen content of rice plants from vegetation cover rate of rice obtained by a simple image measurement, Photogrammetry and remote sensing confference, vol 46, No 4, 2007.

[5]. USGS, Landsat \& Users Handbook Chapter http://landsathandbook.gsfc.nasa.gov/data_ prod/prog_sect11_3.html

[6]. Ocean Optics, Calibrating the Wavelength of the Spectrometer, http://www.oceanoptics.com/Technical/wa velengthcalibration.pdf. 